Portland State University

PDXScholar

Spring 6-16-2021

\title{
Exploring the Intersections and Interventions of the Juvenile Justice System through a Case Study Approach
}

Adriana Cordova-Perez

Follow this and additional works at: https://pdxscholar.library.pdx.edu/honorstheses

Part of the Juvenile Law Commons

Let us know how access to this document benefits you.

This Thesis is brought to you for free and open access. It has been accepted for inclusion in University Honors Theses by an authorized administrator of PDXScholar. Please contact us if we can make this document more accessible: pdxscholar@pdx.edu. 
Exploring the criminal justice system through a case study approach.

Exploring the Intersections and Interventions of the Juvenile Justice System through a Case Study Approach

\section{By: Adriana Cordova-Perez}

An undergraduate honors thesis submitted in partial fulfillment of the requirements for the degree of a

$$
\text { Bachelor of Arts }
$$

in

University Honors

And

Criminology \& Criminal Justice

Advised by: Dr. Christopher Carey

Portland State University 2021 


\section{Introduction}

For my thesis, I used a case study approach to analyze what we can learn about the Criminal justice system by exploring the life history of a juvenile offender. Research data was collected through an interview with a juvenile offender. Secondary sources such as literature review will also be examined to better understand the juvenile justice system. The interview will have several questions to better understand the life of the juvenile prior to them becoming part of the criminal justice system and also the question about life while in the youth correctional facility. Through those questions, I hope to better understand the criminal justice system. Also, to have a better understanding of how the criminal justice system has affected the life of an individual who has been part of it.

\section{Review of Literature}

American activist for children's rights Marian Wright Edelman, once said 'I've been struck by the upside-down priorities of the juvenile justice system. We are willing to spend the least amount of money to keep a kid at home, more to put him in a foster home and the most to institutionalize him. As a "society" the community is more invested in institutionalizing young people instead of seeking ways to help them find their passion in life. This has been an ongoing struggle for many years. The problem is the criminal justice system has failed many young individuals who have become a part of it.

Examining different methods of incarceration is important in order to better understand how various methods could help people who are incarcerated. In his classic ethnography study, Gresham M Sykes (1958) was the first to coin the term "pains of imprisonment". Sykes describes 
five separate categories of "pains": the deprivation of liberty, the deprivation of goods and services, the deprivation of heterosexual relationships, the deprivation of autonomy, and the deprivation of security (Skyes, 1958). These categories are significant in understanding how the pains of imprisonment can have a positive and or negative impact on the alternative forms of incarceration.

Alternate forms of incarceration have been analyzed for many years in the Criminal Justice field, these alternative forms allow for a better understanding of how the Criminal Justice system can intervene in the life of a young offender (Chamiel Elad, 2018). Looking at different forms of incarceration is important because it gives a better understanding of what helps reduce recidivism. For example, in a study done by Chamiel Elad, "House Arrest" or "Developmental Arrest"? A Study of Youth Under House Arrest. International Journal of Offender Therapy and Comparative Criminology: Official Organ of the Association for Psychiatric Treatment of Offenders the study examined fourteen different young people who were under house arrest. The study established six key themes. They were: "the experience of detention and its challenges, the use of regular routine and time, emotions and self-reflection, peer relationships, relationships with parents and supervisors, and interaction with therapeutic staff and probation services" (Chamiel Elad, 2018). The two research questions were: "How do adolescents experience house arrest? How does house arrest affect them and affect the developmental processes of adolescence?" Overall the research delves into the significance of each theme as well as the results which found it was very difficult for the participants to complete their time under house arrest without any kind of difficulty (Chamiel Elad, 2018). The chart gives examples of each theme and its findings, the number next to each theme is the number of participants. The terms the boys used to describe their time under house arrest were, "Not an easy time," "Very 
difficult," "Frustrating" (Chamiel Elad, 2018). These terms demonstrate how difficult it was for these boys to serve their time under house arrest. They served their sentence but also had to adjust to their new form of incarceration resulting in a frustrating environment. The chart helps better understand the research in this thesis by looking at different forms of incarceration and examining what the effects of an alternative form of incarceration has on the adolescents under house arrest. Moving on, the study also found there were aspects which included difficulty sleeping, damaged relationships with family members and friends (Chamiel Elad, 2018) these aspects demonstrated the difficulty of serving time for the boys and family members. It did not only affect the boys ,but also those who were living in the same house. It is important to examine how different forms of incarceration methods can help different types of people. Taking into consideration how this form of incarceration harmed the social relationships with family members and the added difficulty the youth faced with personal obstacles as well, it can be concluded that this form of incarceration is not suited for everyone. Nonetheless, it is important to analyze and learn about house arrest as a different form of incarceration because it offers an alternative way of serving a sentence.

\begin{tabular}{|l|l|}
\hline The experience of detention and its difficulties (14) & $\begin{array}{l}\text { The boys noted difficulty and the feeling that they were being } \\
\text { punished. Difficulties included mental emotional difficulties, } \\
\text { dependence on others, lack of independence, loss of privacy, } \\
\text { and social hardship }\end{array}$ \\
\hline Daily schedule and utilization of time (14) & $\begin{array}{l}\text { One group of boys managed to formulate a clear and } \\
\text { productive daily schedule compared with a second group } \\
\text { whose agenda was chaotic }\end{array}$ \\
\hline Emotions and self-reflection (12) & $\begin{array}{l}\text { The boys felt various emotions alongside feeling of having } \\
\text { grown and learned from the difficult situation }\end{array}$ \\
\hline
\end{tabular}




\begin{tabular}{|l|l|}
\hline Relationship with peers (12) & $\begin{array}{l}\text { Friends constituted a significant support factor for the } \\
\text { detainees. Distance from friends increased negative feelings } \\
\text { among detainees }\end{array}$ \\
\hline Relation to parent and supervisor (13) & $\begin{array}{l}\text { An absolute majority reported improvement in the level of } \\
\text { contact with parents fro various reasons }\end{array}$ \\
\hline Contact with therapeutic worker and probation service & $\begin{array}{l}\text { An ambivalent attitude toward the probation service was } \\
\text { reported, which was perceived as a contributing factor, but } \\
\text { also as an aggravating factor }\end{array}$ \\
\hline
\end{tabular}

(Chamiel Elad, 2008)

Peter Greenwood, a researcher in juvenile delinquency, analyzed programs that help youth not go down a path of delinquency and helped intervene in their negative lifestyles. In his article Greenwood reviews the methods used to identify the best programs, explains how program success is measured, provides an overview of programs that work, and offers guidance on how jurisdictions can shift toward more evidence-based practices as well as discusses the difficulty in identifying the outcome of the programs (Greenwood, 2008). Greenwood makes a great point by saying the following, "The passage of time cuts both ways. On the one hand, interventions in childhood may have effects on delinquency that are not evident until adolescence. Likewise, interventions during adolescence may reap benefits in labor force participation only in young adulthood. On the other hand, an intervention may initially lessen problem behavior in children only to have those effects diminish over time" (Greenwood 2008). Examining at what point in the youths life intervention is done is significant because there is a difference between intervention at a young age in comparison to intervening during adulthood. In this passage the question regarding at which point someone should intervene in a child's life is raised. Furthermore, in that same passage Greenwood states, it is important to look at programs which help adolescents however, it is just as important to keep in mind how each individual may have a different reaction to the intervention. As stated in the quote, intervening at a younger age may benefit only a select part of their life. The problematic behavior found in the youths early 
life can be changed, but sometimes that same behavior can return later on in their lives. Researching different types of interventions is significant to analyze how each interventional method benefits individual young adults. Research found that home visits by the registered nurses involved in the program had a positive effect on the life of the child and the mother. Children who were part of the program did experience less child abuse, showing us how early prevention can have a positive impact on the life of the child. Not only were home visits significant but also programs that focus on specific skill issues such as behavior management, interpersonal skills training, family counseling, group counseling, or individual counseling also had positive effects on institutional settings (Greenwood, 2008).

Overall, Greenwood has discussed the techniques used to classify the best programs in his report "Prevention and Intervention Programs for Juvenile Offenders The Future of Children". In the study, Greenwood discusses the importance of analyzing the effectiveness of the programs. Greenwood states, "In summary, defining successful programs is challenging, both because of design flaws in many research studies and because comparing inconsistent findings is difficult. But some metrics must be designed to allow jurisdictions to begin to implement programs that have been proven effective. Blueprints is the most promising of these techniques, though others such as meta-analysis hold promise" (Greenwood, 2008). Therefore it is important to examine the lives of those who have been impacted by the criminal justice system because it allows for an inside look at the different impacts the system has on the individual's life. Also, the findings serve as an opportunity to better understand the system and areas of improvement. Those areas of improvement are significant for the future of youth who may fall victim to recidivism and struggle to stop their cycle of committing crimes. 
The prevention of delinquency is important to examine because by doing so one has a better understanding of what can be done to help someone not become part of the criminal justice system. Too often there is hope someone will not recidivate once part of the system but, what is significant is to look at what is being done in order to prevent delinquency before the youths become part of the system. Therefore, research conducted by Jackline Berghal provided a better understanding of the prevention of juvenile delinquency. Prevention of juvenile delinquency is also important to analyze because it is important to examine different ways in which prevention can be achieved. A great point of prevention was discussed in the literature stating that examining the correlation between school dropout rates and delinquency is important because a strategy is needed to recognize early school disengagement and potential dropout from education (Berghal, 2015). Early warning systems can be an invaluable tool for identifying school disengagement trajectories and preventing High School dropout in teens. The research that is conducted nowadays is focused on developing early warning systems that identify youth who have started to disengage and are at risk for dropping out of high school. The intent of these efforts is to identify at-risk youth early enough so that effective intervention strategies may be implemented (Berghal, 2015). The following are taken into consideration when looking at potential warning signs: indicators of course failure, poor attendance, GPA, a low achievement on standardized test scores, and school suspensions. The purpose of Berghal's report, therefore, is to address the gap in the literature by examining the utility of the school disengagement warning index to predict school dropouts and the set of problem behaviors that emerge during adolescence and continue into young adulthood (Berghal, 2015). The main focus was the court records in the research which focused on the effectiveness of a prevention program administered by a county juvenile court. The study was significant in the understanding of how such a 
program can have a positive impact on the life of someone who has not fully become part of the juvenile justice system yet. This study differed from others because it did not have youth who were part of the criminal justice system, instead it's focal group was teens who were at risk of becoming part of the Juvenile Justice system. Overall, the support given to the youth allowed them to better their behavior and be successful. An important finding was the significance of having both parents in the life of a youth. Those who had both parents had a less probability of engaging in delinquency.

There is significant research about programs helping youth steer from a life of delinquency and not become part of the criminal justice system. The debate surrounding the importance of education from an early age is also significant when discussing points of intervention in the criminal justice system. In a study done by Emily A. Mann titled "Early Intervention and Juvenile Delinquency Prevention: Evidence from the Chicago Longitudinal Study", found that children who had attended pre-school were associated with decreases in juvenile delinquency incidences, frequency and severity by 18 years of age. (Emily A. Mann, 2006). The study was significant in demonstrating the importance of early education in the life of a child. The study found that not only is it important to incorporate education into the life of a child early on but also maintain the child in an environment where they will continue their education (Emily A. Mann, 2006). It is important to note that children who had the support of their parents were more likely to continue with their education.

\section{Methodology}

A case study was chosen as the research method because it would allow for a close examination of the data collected. An interview was conducted to answer the research question, 
"Using a case study approach, what can we learn about the Criminal Justice system from exploring the life history of a juvenile offender?" This research was conducted under PSU Institutional Review Board (IRB) \#217195-18. Through an interview, the thesis question was answered by exploring the life history of someone who was part of the juvenile justice system. A series of questions were created by the researcher for the interviewee, who had agreed to be part of the research, to answer. He was chosen for this research because of his life experiences and involvement in the juvenile justice system. For privacy reasons, the name of the interviewee was stripped from this thesis, the name $J$ was used to identify him. The questions were created by having questions centered around the life of the interviewee, the juvenile justice system, and points of intervention in his life. Questions asked during the interview can be found in the appendix section of this paper along with the IRB forms. Additional questions were asked as they arose. All identities such as name, date of birth, hometown, and other locations were script from the interview. The interview was structured with the interviewee sharing his life story and how he became part of the juvenile justice system. A second interview was conducted with additional questions. The interview was done through a visual and audio recording method in March of 2021. The questions were focused on not only the life of the interviewee but also points of intervention where the justice system failed to intervene.

\section{Case study}

\section{Background}

The interview process consisted of questions being asked to the interviewee, in this case the offender, about his time within the criminal justice system. J was raised by his father and grandmother in a suburban neighborhood for the first eight years of his life. His mother was not 
in his life from a young age. She was fighting her own battles with addiction and mental health, his father and grandmother became the sole providers. As the years went on his father became an alcoholic and was not as attentive to $\mathrm{J}$ as he once was. $\mathrm{J}$ enjoyed spending time with the family of his neighborhood friend. He would spend hours with this family and they quickly became close to him. J would spend hours with them after school, have dinner with them and they began to form a very close relationship. The youngest boy in the family was J's best friend, they went to the same elementary school and would spend the evening together at his friend's house. The best friend's mom would volunteer at the elementary school allowing her to get to know her son's friend, J, even more.

With regard to J's life, it is important to discuss a very crucial moment in his life, his first encounters with law enforcement. That first encounter was when his father received his first DUI, his dad later received another one, resulting in his father having to install a breathalyzer in the car. Consequently $\mathrm{J}$ would have to breathe into the breathalyzer every time he got in the car with his father. Another impactful moment in J's life was the passing of his father, the morning after Christmas he found his father lying dead in his bed. Shocked, he went to tell his grandmother. Without any time to process what had happened, J was sent to his sister's home. J was never questioned by any kind of authority about what he saw or how he was coping with his fathers death. Instead, he was sent away from home to be with his sister, who lived down the street, and spent time there while things calmed down. In disbelief, his sister was shocked to hear the news of her fathers passing. She was not able to take J under her custody because she had her family to take care of and would not be able to handle the responsibility of another kid. J's best friend's family was also not able to take him in because of the court process. The only other 
option was his uncle, so he moved in with his uncle and his wife. At ten years old J was now starting a new life with his uncle and aunt in a new town.

Living with his uncle was not what was expected. J was abused mentally, physically, and emotionally. Not only was he abused by his uncle he also had very high expectations of J. He was expected to be the best at all he did, do his best at anything assigned to him. They lived on a farm and with that came many responsibilities. $\mathrm{J}$ was expected to do many different kinds of chores throughout the farm. These chores were to be done after he came home from school. He had to balance his academics, sports and the responsibilities of the farm all at once. This became very difficult, tiring, and overwhelming for him but he needed to get everything done in a timely manner or else there would be consequences. Such as abuse mentally and physically.

As the years went on $\mathrm{J}$ was abused and neglected by his uncle until one day $\mathrm{J}$ could not take it anymore and killed his uncle. It is important to look at the reasons why $\mathrm{J}$ committed the crime and what led him to do it. From an early age, J was abandoned by his mother and not cared for by his dad. Both parents had a history of drug abuse that did not allow them to give as much attention to $\mathrm{J}$ as he needed. During the interview $\mathrm{J}$ shared his story from his early childhood to where he is at today. His story was heartbreaking and it is a story that needs to be told to better understand how different systems failed him and to look at points of intervention. Throughout J's life, there were three main points where someone could have intervened. The three main points of intervention were the family encounter with the Department of Human Services (DHS), an ultimatum given by his grandma, and a time a state trooper was sent to his school to see how $\mathrm{J}$ was doing. Overall, his story is an example of how the system failed him. 


\section{Themes}

The interview process was important in regards to learning more about the life story of J. Throughout the interview he shared his life experiences, such as: childhood, upbringing, living with his uncle and his time in the juvenile correctional facilities. As he shared his story there were several themes that came up such as: resilience, mentorship, ability to set short and long term goals, interactions, and self-blame. Each of these themes are significant in learning about $\mathrm{J}$ and how he was able to navigate through the justice system.

\section{Resilience}

Throughout the interview, one of the themes brought up by J was resilience. The capacity to recover quickly from an event or situation was something $\mathrm{J}$ had to do. At the age of eight $\mathrm{J}$ had to face the tragedy of finding his dad dead the morning after Christmas. J did not have time to process what had happened, as he was quickly sent to play with the neighborhood kids. In the interview J states "The morning after Christmas, I woke up and I went to basically wake my dad up like I used to every morning and he was unresponsive, he had passed in his sleep. I was nine, it was in 2005, December 26, he passed. That was a big turning point. That's when things really changed so my grandmother pretty much told me to like to go play with my friends in the neighborhood. I wanted to go hang out with Jackson and basically go see his parents, but I wasn't I wasn't able to. Cause they were kind of further out from where we lived. So I hung out with a couple of different friends and then I went to my sister's apartment complex, where she, my niece and my nephew lived. I told them what happened and they were like, pretty tore up about it. My sister's freaking out because she couldn't take me in because she already had two kids, she had no space in the apartment complex to take another kid. She didn't know where I was gonna go. No one knew if DHS was gonna take me or anything like that. So I hung out for 
the better part of the day just walking around the apartment complex, not really knowing what to do. Then a bunch of cops showed up eventually after that, when I saw the cops, I just pretty much bounced. Then I came back later that night, and my uncle and my aunt had shown up on my father's side, on the Baker side of my family. They pretty much said that they were going to pack us up and move us down from where I was living to my uncles” (J, 2021). J did not have time to process what had happened or what was going on. Not only did he not have time to grieve the death of his father, but there were also no DHS workers who checked up on him or any police officer. Nonetheless, $\mathrm{J}$ was able to find the strength as a young boy and move forward. Another example of J's resilience is his overall story. Throughout his time incarcerated J was able to find ways to better himself, graduate from high school, college, receive his personal trainer license, barbering license along with many other accomplishments. He beat all odds that were stacked against him.

\section{Mentorship}

Throughout his incarceration J quickly learned the importance of using his time productively. He began to read books, hang out with the "elite kids", work out, learn new skills, etc. $\mathrm{J}$ became a mentor while serving his time at MacLaren Youth Correctional Facility. J states during the interview, "So I ended up transferring from Chemeketa after I got my two year started going to Oregon State University full time. Then I started teaching the barbering program at MacLaren full time. I decided to spend most of my afternoon time either mentoring kids or I was in the gym. After a while, I got certification as a personal trainer, and I would spend hours at the gym, working with staff members working with youth. And then I was offered a position after a while to be a living mentor and what we call the intake unit of McLaren. And pretty much my role was to live full time with kids age pretty much 12 to like 18 or 19 years old. And these kids 
were going to be with me for 30 to 45 days, and it was my job to basically get them ready for long-term living. Now, these kids would come in, they need to do three to six months of treatment. Some of them needed to do three to five years, some kids were doing life. It was my job to try to connect with them. And kind of instill within the kind of mindset that I had developed over all those years and help them give them an advantage. A lot of it turned out to be a lot of the escalation tactic stuff, getting kids to slow down and really think about the decisions that they're trying to make and help them think really, really long term" (J, 2021). J became a mentor to other kids because he knew how difficult it was to navigate the system. He became that role model that for so many years he did not have. J was given the opportunity to be a mentor for younger kids and he did an amazing job.

\section{Ability to set short and long term goals}

Setting goals for oneself is very important because by doing so we feel accomplished when the goal has been reached. J set several goals for himself throughout his time incarcerated. He knew his time could be used to better himself and accomplish the goals he had. His ability to set both short and long-term goals allowed him to become a better version of himself. "I started looking at how people were doing their time. I mean, you got the knuckleheads and the idiots that are just kind of fucking off. And then you got another group of guys that are trying to figure it out, but they keep slipping up. And then you had the kind of what I considered more the elite kids. They were going to college, they were getting certifications, they were taking their time seriously, they never got in trouble. They had a really good way of communicating in terms of like with other youth, with other staff members, with volunteers, everybody they were well respected. I started emulating and basically hanging out with them a lot more. And then I made what they did what I did. After a while I was one of the older guys that was living on the unit 
that had a lot of privileges. I had a lot of opportunities to pursue the things that I wanted to when I first got locked up at a 1.1 GPA. I only had 11 credits, I was about to be 19 years old, and I was supposed to graduate that spring summer term. The first school that I saw myself with my parents or with my best friend's parents was basically to graduate high school. I told him that I not only wanted to graduate high school, but I wanted to graduate with three points that spring or summer. I took accelerated courses, I took about seven, eight classes a term. I ended up graduating on time with three points. Immediately after that, I was pretty surprised with myself. I'm just saying, Okay, I'm not as dumb as hell, I can't learn. I'm like, Alright, what else do I want to do? And my best friend's parents are like, well, you need to go to college, you need to basically find a way to give yourself an edge when you eventually come home. So I graduated when I was 19, I decided to be hard headed and go a different route. I wanted to be a barber, they had a barber program offered there. Entered the barber program when I was 19. A lot of the older guys that were kind of like in the living unit that was living on at the time and everybody else that I kind of hung out with were all barbers. They were all doing really good with their time. And that's what the plan was to become a barber then go home. Basically cut hair, make money, and be productive. So I wanted to get that because I didn't want to just rely on a college education to get me far because even with a college education, you still got to check that box. So I'm just I'm gonna pick up a trade. So I went to the barber program for two years and ended up getting my barbering license. And then from there, I started taking part time classes at Chemeketa" (J, 2021). J turns his life around the moment he begins to realize his potential. He begins to set short and long term goals for himself and in the process he realizes all he can do. J begins to believe in himself and sees all the great things he is capable of. It was not expected of him to graduate high school considering his low GPA. Nonetheless, he turns all that around and 
not only graduates high school but also college and gets certified as a personal trainer and his barber license. Another example is the goal he set for himself to run and finish the MacLaren Marathon. During the interview J shared his experience with the marathon and the discipline he learned from it. He stated, "I think I was about 21 or 22 . When I decided I wanted to try out the marathon program that they had offered there, they had a running program. And each year they run a marathon. So my first year I ran a marathon. I ran in like 5 hours 15 minutes. After I ran that marathon, I started adapting a lot of what I learned from that process to how I kind of did stuff with school with youth with kids everything. When you think about doing something really hard or difficult, you see, you see Everest, you see the thing that you're trying to accomplish, and it feels like it's like overbearing, and it's really difficult and hard. What I would do is, I would tell myself, okay, so I want to run a marathon in April. So I'm going to back this up six months in October, this is what I'm going to do in November, this is what I'm going to do, December and so on. Then I would break it down, not just for that month, I'd break it down by week, and then I would break it down by day. Next thing, you know, I have a workout blog, I have a diet log, I have what stretches I need to be doing, I know what weight I need to be at. I took that example. I applied it to different areas where basically kids that struggle with either school akademia losing weight, how to build relationships and trust with staff members, how to rebuild relationships with family members. I started using it to really help as many kids as I could. I lived in that unit roughly for about two years, ended up running some more marathons and then I got fully certified as a personal trainer" (J, 2021).

\section{Self Blame}


One of the most important themes discussed during the interview was self blame. Throughout his childhood J blamed himself as the reason why his mother had abandoned him. Not only his mother but also his aunt and, later in his life, grandmother. In his eyes he was the reason why they left and he put the blame on himself for many years. He questioned his worth and felt like he was to blame for everything. He states, "We go back. After about three months, things started getting worse bit by bit and then my aunt pretty much on another day when my uncle was gonna be gone all day, she comes up to me, she says, Hey, I have to leave, I need you to help me pack my truck. And like pretty much, I'm going to drop you off at your grandmother's. That's when I'm just like, wow, that sucks, I'm screwed haha. And I help her pack her bags. I remembered just being real low and just trying to like put stuff together in my head. At first, I felt bad, I felt sad. Then I started to resent my aunt for being able to abandon me and just leave the entire situation itself. Which felt like the same situation with my mother. Then when my grandmother got moved out too I felt like I was getting abandoned by her, and then when my dad passed away, I felt like I took a lot of that blame on myself, oddly, which makes no sense. As a kid, when you have a bunch of bad stuff happen around you, and you're the only common denominator around it, I internalized all that stuff that had happened. And I pretty much made it seem like it was my fault, like I was the problem" (J, 2021). Having lost his mother at an early age due to drug addiction caused a lot of harm on J. Throughout his life he did not have a mother figure to lean on as the only two mother figures he had left him.

Throughout his life he blamed himself as the reason why his mother, grandmother and aunt left him. He put a lot of the blame on himself from an early age without fully understanding why his aunt decided to leave his uncle and why it was best for his grandmother to be placed in a retirement home. After his grandmother was placed in a retirement home he visited her in hopes 
that she would intervene and take him out of his uncle's home. However, his grandmother gave him an ultimatum of staying with his uncle or being taken into DHS custody. J continues on to say "So I get dropped off at my grandmother's place. My grandmother's like, why are you here, and I pretty much have to break down the situation. Then she's like, pretty much telling me that, you know, you have two options that you can either stay with your uncle or you can go to DHS. That is basically 'no' either way, it's not going to be a good situation. I didn't really trust my grandmother at that point anymore, because I had been separated from her for like almost a year at that point. I hadn't seen her the whole time. My uncle comes back, he goes ballistic. Then day by day, week by week, month by month, I tried to find a way to survive" (J, 2021). These two points in his life where he felt like no one was there for him are important because they are examples of how alone he felt. $\mathrm{J}$ began to put the blame on himself for everyone leaving him. Any adult that came into his life seemed to abandon him shortly after coming into his life. The only adult he had was his uncle who abused, and did not care, for him. There were no female role models in his life who would care for him. A key component in the development of a child is the bond they share with their mother (Ben- Joseph, 2018). However, J did not have this such bond, his mother abandoned him at a young age, his grandmother and older sister could not care for him and his aunt left $\mathrm{J}$ and his uncle after many years of tolerating the abuse from him.

\section{Points of intervention}

There were three main points of intervention throughout J's life where someone could have intervened. Had someone intervened at any point during these three moments of his life his life would have been very different. The points of intervention were as follows: the time his best friend's family is not able to be granted custody of $\mathrm{J}$, a conversation with his grandmother and 
when a state trooper visits him at school. However, there was no intervention and now these moments serve as examples of how the criminal justice system failed him.

The first point of intervention was J's best friend's family and DHS. After the passing of his father J was not able to be taken into custody by his half-sister for personal reasons. J's best friend's family wanted to take him in but were not able to because the court gave privileges to family members. The only family member that was able to receive custody of $\mathrm{J}$ was his uncle who lived out of town. This now meant $\mathbf{J}$ would have to move to a new city, form new friends, join a new school and live with his aunt, uncle, and grandmother. This point of intervention is important because DHS never fully did an investigation to determine if his uncle was a suitable person to take care of $\mathrm{J}$ in the siercumatces $\mathrm{J}$ found himself in. This is evident because later on in the life of $\mathrm{J}$ he is abused by his uncle which had a profound impact on the development of his life later on.

The second point of intervention is the time $\mathrm{J}$ visits his grandmother at her retirement home. For many years $\mathrm{J}$ lived with his grandmother, uncle, and aunt. As the years went on his grandmother's health deteriorated resulting in her placement in a retirement home. $\mathrm{J}$ visits his grandmother at the retirement home as a means of escaping the misery he was living with his uncle, he was being abused mentally, physically, and emotionally. His aunt had left J's uncle consequently $\mathrm{J}$ felt alone and in need of someone to intervene with the abuse being done to him. As a result, J visited his grandmother at the retirement home. J's grandmother gave him an ultimatum of either staying with his uncle or being taken away by DHS and placed in a foster home where things may not be any better. His grandmother assured him he would be placed into the foster care system where no one would care for him. Without an escape, J decided to stick it out and stay with his uncle. Although his grandmother may not have been able to do much 
herself in terms of taking care of $\mathrm{J}$ this is another seduction in his life where someone could have intervened but did not.

Finally, the third main point of intervention was the time a State Trooper was sent to J's elementary school to check on him. The state trooper is sent in to check up on J by the request of his aunt because this was her way of knowing $\mathrm{J}$ was okay. A normal day at school turned out to be a moment where someone should have intervened. J was asked to visit his principal's office where the state trooper was waiting for him. However, J does not speak with the state trooper nor does $\mathrm{J}$ tell him about the abusive behavior he endures from his uncle. Instead, $\mathrm{J}$ leaves the principal's office and does not speak with anyone. The state trooper arrives at the school without a DHS worker or any state worker. What should have happened was that a DHS worker should have talked to $\mathrm{J}$ and questioned him about what was going on at home. During the interview with $\mathrm{J}$, he shares this story and mentions he had visible scarring and bruising but he was still not further questioned by the state trooper or any faculty at his elementary school. It is easy to want to blame the little boy for not speaking up but taking into consideration the abuse and neglect he had faced for so long it makes sense why he would be afraid to speak up. These three points of intervention serve as examples of how the criminal justice system failed $\mathrm{J}$.

\section{Interactions with Law Enforcement}

From a young age the interactions between $\mathrm{J}$ and police officers were not positive. The times he did get to interact with law enforcement were the times his father was being stopped or questioned by the police. $\mathrm{J}$ began to have a negative impression of police officers because all the interactions between police officers and his father were of his father getting into trouble. $\mathrm{J}$ remembers being a kid and having to breathe into the breathalyzer that was placed in his dad's car as a result of his DUI. J states, "And it was around, I think it was like four or five years old. 
When I first saw my dad get pulled over by a police officer and got in trouble and got a DUI. And that was my first time having a one-on-one experience with a police officer. It happened right outside of my house. One cop pulled him over, and then another cop showed up. My dad failed the sobriety test, and they took him into custody and gave him a DUI. Then he got his rights basically back to driving and stuff like that. But that kind of ingrained in my head that like cops weren't really good because they just locked my dad up. I didn't really understand what my dad did wrong. I knew that he drank and knew like he smoked weed and did other stuff like that. But I didn't like to understand why it was bad. So I didn't like cops and then about a year later, like right after that incident, he gets another DUI again, and they have to put a breathalyzer in his truck" (J, 2021). It is clear these interactions were ingrained into his mind as negative and they shaped how he saw cops. As a result of these interactions his perception of cops changed and would make it difficult for him to talk to cops and later in his life open up and speak the truth about the abuse that was going on while living with his uncle. While living with his uncle J's aunt had a state topper visit J at his school. J remembers the visit by saying, "This was probably like six months to a year after my aunt left. She sent a state trooper to come check on me when I was over Middle School. I got pulled out of class by the principal. I'm thinking that I got in trouble for like, I don't know, selling weed or something like that. You know, I thought it was like screwed. Then the first thing I was going through my head was like, Well, you know, uncle was gonna hear about me having to talk to a cop so i'm fucked. I got pulled into the office and was like, Hey, we want to know about your living situation. We want to know how things are going. What's up with you and your uncle? I'm just like, why do you want to know any of this? I'm fine, leave me alone. It's like, well, we were basically sent here by your aunt, she was worried about you. We were told to basically inquire about your safety and what's really going on. I pretty 
much associated them like so you want me to basically talk to you and you were sent by the person that abandoned me let me on my own. No, I don't want to talk to you. From that moment on, I pretty much like you know, chalked it up in my head that like whatever is gonna happen is gonna happen. I'm just gonna get through it on my own. I spent the remainder of six or seven years living with my uncle up until I was 17' (J, 2021). Although the trooper was sent by his aunt to check up on him, neither the principal nor any faculty member from the school ever followed up with $\mathrm{J}$ after the trooper came to the school to check up on him. J did not open up about what was going on at home because as he mentioned "why would cops care about my wellbeing if all interactions I had were negative" (J, 2021). The visit is significant because there should have been more of an investigation from the trooper and the school on what was happening at home. The trooper had mentioned the reason for his visit which was to check up on J however, J did mention he would not be speaking to anyone about what was happening at his uncles. At this point in J's life there should have been someone who intervened in the abuse that was being done to him. His aunt had all the right intentions to send the trooper in hopes he could help but it failed and no one intervened. Another interaction with law enforcement that failed to intervene was during the interrogation for the killing of his uncle. The detectives that spoke to $\mathrm{J}$ wanted to know more about why he had killed his uncle, and what were his motives to kill. However, $\mathrm{J}$ did not share any of the information with the detectives, instead he kept it all to himself. J stated the following, "But the two detectives that were talking to me weren't trying to confirm whether or not I did it. They were just trying to clarify what life looked like when I was actually living there. They wanted to know why I have so many scars on my body? Why do you have fresh wounds? Why do I have xy \& z and I wouldn't say. I didn't comply and really didn't answer those questions. I just pretty much told him I didn't know shit” (J, 2021). This was yet 
another moment in his life when someone could have intervened and found out the reason why $\mathrm{J}$ committed the crime but instead nothing was done.

\section{Positionality}

After the first time hearing J's stories I could not help but feel so many different emotions. Shortly after the interview was done I began to reflect on how I was feeling at that moment. Upon hearing what J was telling me about his life I thought "I'm feeling fortunate to have lived the life I did and had the opportunities I had. I attended good schools, lived in a good neighborhood, participated in extracurricular activities at school and enjoyed my life as a kid. As I grew up I continued to live a very similar lifestyle. Both of my parents were always there for me, I never questioned if I mattered, I always had the support of my family and a great support system. My older siblings paved the way for my academic life. I was always compared to my older siblings in a positive way but I always knew I had the freedom to do and be whatever I wanted to be. I was never in trouble with the police. The group of friends I had were positive. Growing up my neighborhood friend lived a different lifestyle than me but we were just kids and that did not matter. The system has failed so many times, so many children, we cannot blame the kids for their reactions to situations they have no control over. They never learned how to handle their emotions" (Cordova-Perez, 2021). Before the first interview I had never heard his life story. Listening to him tell his life story allowed me to better understand the abuse he went through and why for so many years he decided to keep quiet about the abuse he lived. I also questioned how the adults in his life did not intervene when the opportunities arose. There were three main points of intervention and not once were any of them successful. For some people it would be easy to put the blame on someone and hold resentment for not doing something to help the innocent boy. When $\mathrm{J}$ spoke about how pointless it is to hold a grudge I found it surprising that he would think 
like that because I could not wrap my head around the fact that there were so many people who did nothing to help him out and yet he felt no anger toward those people. Weeks after the interview I continued to feel the same emotions of sadness, anger, astonishment but also happiness that at the end he worked on becoming a better person. He became the person that for so many years he did not have. Self- efficacy is a word I continued to think of as he began to share all of his accomplishments. Although I do not know him personally I was so proud to hear how far he had come and all the wonderful things he has yet to accomplish. It fills me with joy to know he now has an amazing support system and family who loves him.

\section{Implications}

There were various takeaways from the criminal justice system research that came from looking at the life of a juvenile offender. The most important being the missed opportunities for intervention before J's involvement in the Criminal Justice system. The three main points of intervention were the failure of placing $\mathrm{J}$ in a home where he would be cared for properly, the ultimatum given by his grandmother, and finally the visit to his elementary school by the state trooper. Everyone one of these interactions was significant in the hopes someone would intervene and save the little boy from the abuse happening at home. However, that was not the case and as the years went on those around him ignored the signs of abuse. Throughout this research I also learned the importance of structure within the Criminal Justice system. However, this is limited to the person who is incarcerated. The story of $\mathrm{J}$ is sad and inspirational seeing all he accomplished while incarcerated. Nonetheless, it is important to acknowledge this is not the case for everyone who goes through the Criminal Justice system. J had the ability to set long and short term goals for himself which led him to accomplish a lot while incarcerated. He realized it was up to him to change his ways or else it would be an ongoing cycle of going in and out of the 
Criminal Justice system, as he saw with other offenders time after time. The story of $\mathrm{J}$ is inspirational for all he was able to accomplish and overcome on his own and with the help of a great support system.

\section{Conclusion}

The purpose of this case study was to find what can be learned about the criminal justice system by exploring the life history of a youth offender. After the researching and interview one can conclude there were three main points of intervention in the life of the offender. The first was the incident with DHS and the family of J's childhood friend. There was never a time when DHS fulfilled an investigation on what would happen with J after his fathers passing. Also, DHS did not question J's uncle prior to him moving in nor did any social worker ask J how he was doing. Although this was mainly a concern of DHS , had there been someone there to intervene, who knows what would have happened to J's life. Similarly with the other two situations, the second being the visit to his grandmother's care home and the visit from the state trooper to his school. During both of these visits there was no intervention from any adult or state worker. Overall, the conclusion is there were several points throughout his life where someone could have intervened and perhaps prevented him from being involved with the juvenile justice system.

\section{Abstract}

\section{IRB Forms}




\section{S Portland State UNIVER 5 ITY Portland, OR 97201 \\ [503) 725-5484 psuirbepdx.edu}

Human Research Protection Program

Notice of Review Not Required Determination

February 19, 2021

Dear Investigator,

The PSU Institutional Review Board (IRB) reviewed the following submission:

\begin{tabular}{|l|l|}
\hline Investigator(s) & Christopher Carey / Adriana Cordova-Perez \\
\hline HRPP a & $217195-18$ \\
\hline Title & $\begin{array}{l}\text { Exploring the Intersections and Interventions of the Juvenile Justice } \\
\text { System through a Case Study Approach }\end{array}$ \\
\hline Funding Agency / Kuali N & N/A \\
\hline Determination Date & February 19, 2021 \\
\hline Expiration Date & N/A \\
\hline Review Category(ies) & N/A \\
\hline
\end{tabular}

The IRB determined this project does not require Human Research Protection Program (HRPP) review under the federal regulations, as the project does not meet the federal definitions of "research" with "human subjects" per 45 CFR Part 46 . A single interview (single-subject case study) does not meet the definition of "research" according to the Federal regulations.

IMPORTANT: In-person interactions for the purposes of collecting data is suspended until further notice. Data collection must be through remote/virtual methodologies until this restriction is lifted $O R$ an exception to perform in-person data collection is granted by Research \& Graduate Studies.

As a reminder, PSU faculty, staff, and students are responsible for maintaining the highest ethical standards when conducting any projects on behalf of PSU, regardless of whether HRPP review is required. Additionally, if there are planned changes to the project, please contact the HRPP prior to implementation of the changes to ensure this project does not require HRPP review.

If there are any questions, please contact the HRPP at psuirb@pdx.edu or call 503-725-5484.

Sincerely,

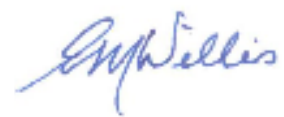

Eva M. Willis, CIP, HRPP Administrator

Research Integrity \& Compliance 


\section{舟 Portland State \\ Human Research Protection Review FORM 1: OVERVIEW \& PRE-SCREENING}

PSU HUNANEEFO FFOECI ON FFOFA

SECTION 1: PROJECT OVERVIEW

A. Project Title: Exploring the Intersections and Interventions of the Juvenile Justice System through a Case Study Approach

B. Study Lead: $\square$ Faculty Investigator $\square$ student Investigator with Faculty Advisor

\begin{tabular}{|c|c|c|c|c|c|}
\hline Name & $\begin{array}{c}\text { Department } \\
\text { or Other } \\
\text { Affiliation }\end{array}$ & Email & $\begin{array}{c}\text { PSU } \\
\text { Affiliation }\end{array}$ & Project Role & $\begin{array}{c}\text { CITI } \\
\text { Training } \\
\text { Date }\end{array}$ \\
\hline $\begin{array}{l}\text { Adriana Cordova- } \\
\text { Perez }\end{array}$ & $\begin{array}{l}\text { Criminology } \\
\text { \& Criminal } \\
\text { Justice }\end{array}$ & acor2@pdx.edu & PSU Student & Student Investigator & $11 / 23 / 21$ \\
\hline $\begin{array}{l}\text { Christopher } \\
\text { Carey }\end{array}$ & $\begin{array}{l}\text { Criminology } \\
\text { \& Criminal } \\
\text { Justice }\end{array}$ & ccarey@pdx.edu & PSU Employee & Faculty Advisor (PI) & $1 / 17 / 20$ \\
\hline & & & & & \\
\hline & & & & & \\
\hline & & & & & \\
\hline
\end{tabular}

-Application will not be processed until the Pl, Co-l, Student Imvestigator or other Key Personnel listed have completed OTI Training.

D. Student Investigator: A faculty advisor MUST be identified above.

Is this project the subject of student's master's thesis or dissertation?

$\triangle$ Yes $\square$ No

E. Funding: Is the proposed project funded through external funding source(s)? $\square$ Yes $\square$ No List Funding Source(s):

Provide PSU Proposal \# or Banner Grant \#:

F. Financial Conflict of Interest: Do any of the investigators have an economic interest in, or act as an officer or director of, any outside entity whose financial interest would reasonably appear to be affected by the results of the study? $\square$ Yes $\square$ No

If yes, describe:

G. Proposed Project Duration:

Anticipated Start Date: February 2021

Total Project Duration (\# of months): 4 


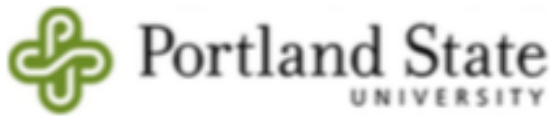

PUHUNFEFO-

FOrCI ON FOFA.

HAF 21770 - 18

H. Objectives: State the purpose and specific aims of the study; include the hypotheses to be tested or the research questions that will guide the study. Use plain language and keep description brief; suggest use of bullet points or list formot.

My case study explores the life of a juvenile offender to Better understand the criminal justice system. In his classic ethaography study, Gresham M Sykes (1958) was the first to coin the term "pains of imprisonment". Sykes describes five separate categories of "pains": the deprivation of liberty, the deprivation of goods and services, the deprivation of heterosexual relationships, the deprivation of autonomy, and the deprivation of security (Skyes, 1958). These categories are significant in understanding how the pains of imprisonment can have a positive and or negative impact on the alternative forms of incarceration.

My case study aims to analyze what can be learned about the Criminal justice system from exploring the life of a juvenile offener.

Using a case study approach, what can we learn about the Criminal Justice system from exploring the life history of a juvenile offender?

1. Rationale: Provide the scientific or scholarly background for, rationale for, and significance of the proposed study based on existing literature and explain how it will add to existing knowledge. Briefly summarize the relevant current context of the study and gaps in current knowiedge. Use plain languoge and keep explanation brief; suggest use of bullet points or list format.

Analyzing on how early intervention can contribute the stop of having young people become part of the cycle of juvenile justice system.

To examine the juvenile justice system to learn more about the system through the life history of an offender. Also, have a better understading how the system has effected the offender in a positive or negative way.

At risk youth are those who are more likely to become part of the juvealle system. They begin with delinquent behaviour and unless there is an intervention they will fall to be part of the criminal justice system. However, there are programs and interventions which have been shown to be suecessful in reducing the likelihood of an at risk youth entering the juvenile justice system. In the article, "House Arrest" or "Developmental Arrest"? A Study of Youth Under House Arrest. International Journal of Offender Therapy and Comparative Criminology : Official Organ of the Association for Pyychiatric Treatment of Offenders the study examined fourteen different young people who were under house arrest. The study established six key themes. They were "the experience of detention and its challenges, the use of regular routine and time, emotions and self-refleetion, peer relationships, relationships with parents and supervisors, and interaction with therapeutic staff and probation services" (Chamiel Elad. 2018). This study provides a better understanding of what alternative forms of incarceration look like. Looking at different forms of incarceration is important because it gives a better understanding of what can be suecessful in different ways. It is important to have a program youth can participate in as it allows them to develop different skills. Youth who had a more structured routine were able to stay motivated and focus on the goals they had (Chamiel Elad, 2018). The structure the programs and or routines provide the youth allow them to develop skills which they then can implement on their own. 


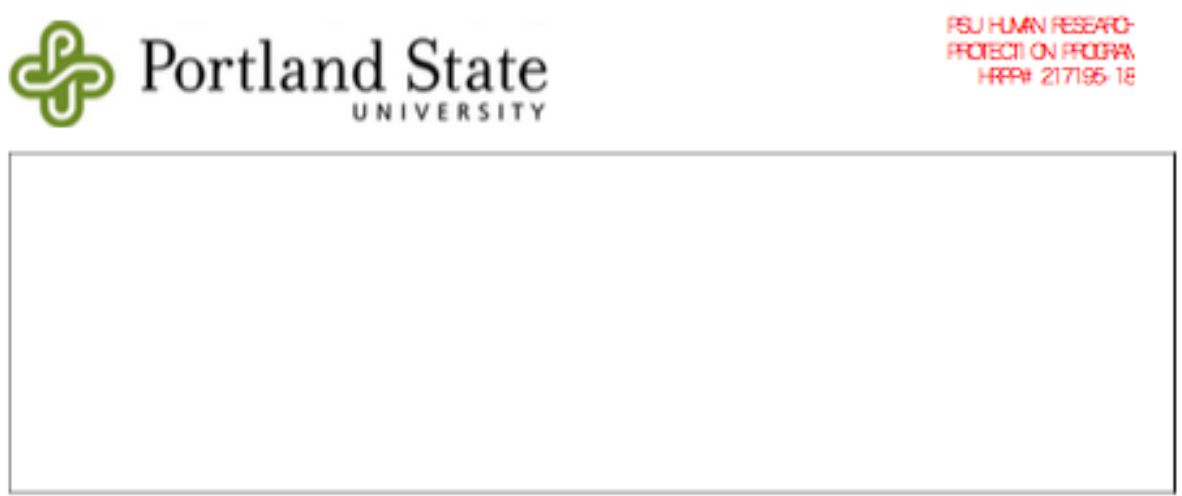

J. Subject Procedures: Briefly describe proposed study activities and indicate how project data will be gathered or generated (i.e., use of existing data, observation, surveys, interviews, experimental/cantrol procedures, etc.). Describe how the investigator will recruit subjects to participate and explain consent/assent procedures, if applicable.

These project employs a qualatative case study analysis. It consist of one participant that will be interviewed about their life history. Data will be collected by recording an interview that will be part free flowing and part question-based. For this project we will use a convinience sample method. In form consent will be obtained prior to the interview.

The data will be collected through an interview format. There will be questions asked to the participant. The particpant will be a previos juvenile offender. Data will also be analyse

Recruitment will be done through a conveinence sample of one person. The person is a colleague outside of PSU

\section{SECTION 2: HUMAN SUBJECTS RESEARCH PRE-SCREENING}

\section{A. RESEARCH DETERMINATION}

1. Is the project intended to be an investigation, a searching inquiry to gather facts, or an examination of a phenomenon?

2. Is it systematic; involving a system, method, or plan that will be employed consistently throughout data collection?

3. Are the results of the project expected to expand the knowledge base of a scientific discipline, or other scholarly field or study, and be publicly disseminated so that the results can be used to develop, test, or support theories, principles, and statements of relationships or inform policy beyond the study?

4. Will the results be applicable to a larger population beyond the site of data collection or the individual subjects? (Check "No" if the conclusions will apply only to the sample population).

\begin{tabular}{|l|l|}
\hline$\square$ & $\square$ \\
Yes & No \\
\hline$\square$ & $\square$ \\
\hline Yes & No \\
\hline $\begin{array}{l}\square \\
\text { Yes }\end{array}$ & No \\
\hline$\square$ & $\square$ \\
\hline Yes & No \\
\hline
\end{tabular}




\section{胥 Portland State}

BU HUAN FESEAO-

If the answer to ALL questions in Section 2A are NO, it is likely the project does NOI meet the federal

STOP definition of research and IRB review is not required. Email this completed form to Research integrity at psuirb@podx.edu for confirmation.

If the onswer to ANY of the questions in Section $2 A$ is YES, it is possible this project meets the definition of research. Additional information is required. Proceed to Section $2 B$ of this form.

\section{B. HUMAN SUBJECTS DETERMINATION}

1. Will investigators use, study or analyze information (or biospecimens) about living person(s)?

2. Will investigators obtain information through intervention or interaction with subjects?

- any communication or interpersonal contact between investigator and subject, such as using in-person or online questionnaires/surveys, interviews, focus groups, observations, or experimental procedures. 
BSH HAN FESERPortland State UNIVERSITY

3. Will investigators obtain, use, study, analyze, or generate identifiable private information (or identifiable biospecimens)?

Identifiable private information:

- information subjects expect would not be made public, or collected within a context which an individual would not otherwise expect to be observed or recorded (such as in their home). AND

- the identity of the subject is or may readily be ascertained by the investigator or associated with the information.

Identifiable biospecimen:

- biospecimen for which the identity of the subject is associated with the biospecimen or may readily be ascertained by the investigator.

If the answer to ALL questions in Section 2B are NO, it is likely the research does NOT meet the federai definition of human subjects and IRB review is not required. Email this completed form to Research integrity at psuirbe⿶凵pdx. edu for confirmation.

If the answer to Question 1 in Section $2 B$ is YES and either Question 2 or Question 3 are also marked YES, the research involves human subjects. Additional informotion is required:

- Form 1: Project Overview \& Pre-Screening is now complete; retain form for submission.

- Complete Form 2: Exemption Certification to determine if the project qualifies as exempt. NOTE: in the Revised Common Rule, previously expedited research is now exempt. 
P Portland State

BSU HUAN FESECO-

FORCD ON PFOPF

IPAP 217195,18

\section{Human Research Protection Review \\ FORM 2: EXEMPTION CERTIFICATION}

Important: Federal regulations specify that certain types of research with human subjects pose low risk to subjects and may qualify for exempt review. The research must meet certain criteria related to risk, and fall into one or more of the categories defined in the federal regulations to qualify for exemption. Complete the sections below for an initial exemption assessment of the proposed research.

\section{SECTION 1: EXEMPTION SCREENING}

1. Is the project greater than minimal risk?

Minimal risk: Probability and mognitude of harm or discomfort anticipated in the research are not greater than those ordinarily encountered in daily life or during the performance of routine physicol or psychological examinations or tests.

2. Will prisoners be specifically recruited to participate in this study?

Prisoner: Individuals confined in a correctional or detention faciilty, including

involuntary assignment to community-based aiternotives to incarcerotion, such as drug treatment focilities.

3. Will the research involve deception?

Deception: Providing false or incomplete information to porticipants for the purposes of misleading research subjects.

4. Will the research involve materials (dota, documents, records, or specimens) that have been collected, or will be collected, solely for non-research purposes?

5. Will alcohol or drugs be administered to subjects as part of the research?

6. Will biological specimens and/or blood samples be prospectively collected from subjects as part of the research?

7. Will data be collected from subjects using non-invasive medical procedures such as collecting blood pressure or temperature?

8. Are live fetuses considered subjects in the research (providing specimens or imaging)?

9. Is this research FDA-regulated?

If the answer to ANY question in Section 1 is YES, the reseorch does NOI meet exemption requirements and does not qualify for exempt rewiew. Do not complete this form. Complete Form 3: Initiol IRB Review.

If the answer to ALL of the questions in Section 1 are NO, the research MAY quallfy for exempt review. Additional information is required. Proceed to Section 2: Exemption Cotegories \& General Criteria. 
$\int$ Portland State

\section{SECTION 2: EXEMPTION CATEGORIES \& GENERAL CRITERIA}

IMPORTANT: A study may involve multiple exemption categories. Please provide responses to each individual category identified below following the instructions and answering all questions provided.

Category 1: Education

Does this study include research on education instructional strategies, such as research on the effectiveness of, or the comparison among, instructional techniques, curricula, or classroom management methods? $\square$ Yes $\bigotimes$ No

If no, skip to Category 2: Interactions

If yes, complete questions below:

1.1 Will the research be conducted in established or commonly accepted educational settings? Describe the educational setting:

1.2 Will the research specifically involve normal educational practices that are not likely to adversely impact students' opportunity to learn required educational content or the assessment of educators who provide instruction?

Describe the educational practices involved and explain why the research is not likely to adversely impact students or instructors.

Proceed to next item - Category 2: Interactions. 
Category 2: Interactions

Does this study include any communication or contact with subjects, such as conducting interviews or focus groups, completing surveys or educational tests, or observing public behavior? $\square$ Yes $\square$ No

If no, skip to Category 3: Behavioral Interventions

If yes, complete questions below:

2.1 Will the research include only the following interactions with subjects? (select all that apply) $\triangle$ Interview procedures with adults only

Focus groups with adults only

Survey procedures with adults only

Educational tests (cognitive, diagnostic, aptitude, achievement) with adults or children

$\square$ Observation of public behavior with adults or observation of public behavior with children

where the investigator does not participate in the activities being observed

2.2 Will data collection include visual or audio recording?

Describe how activities will be recorded, and specify which octivities will be recorded:

Interview will be done using a visual and audio recording method.

2.3 Will the data be recorded in such a manner that the identity of the subjects cannot be readily ascertained directly or through identifiers linked to the subjects?

Exploin how subjects' identity will not be reodily identifioble:

All identities such as name, date of birth, home town and other locations will be stript from the final report.

2.4 Would disclosure of subjects' responses outside of the research not reasonably place the subjects at risk of criminal or civil liability or be damaging to the subjects' financial standing, employability, educational advancement, or reputation?

Explain why disclosure of responses does not pose any of the risks identifled above:

All of the interview questions pertain to things the interviewee have spoken publicly about many times.

2.5 Would disclosure of subjects' responses outside the research reasonably place the subjects at risk of criminal or civil liability or be damaging to the subjects' financial standing, employability, educational advancement, or reputation?

Describe the provisions to protect the privacy of subjects and to mointoin the confidentiolity of doto:

Will use a identity data only password on a drive/computer. If emails are sent the email will be encrypted

2.6 Are children (under age 18) included as subjects?

Describe the specific research octivities involving children: $\quad$ Yes No

2.7 Are prisoners excluded as subjects (except for research aimed at involving a broader population that only incidentally includes Prisoners)?

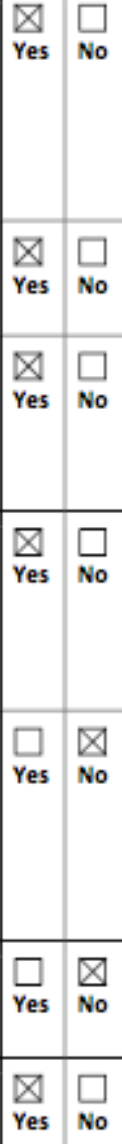

Proceed to next item - Category 3: Behovioral Interventions. 


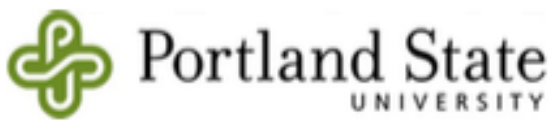

BSU HUAN FESEFO-

FOECTI ON FUFF

HFP: 217195.18

Category 3: Behavioral Interventions

Does this study involve behavioral interventions in conjunction with collection of information through verbal or written responses (including data entry) or audiovisual recording? $\square$ Yes $\square$ No

If no, skip to Category 4: Secondary Research Without Consent

If yes, complete questions below:

3.1 Will subjects prospectively agree to the behavioral intervention and information collection?

3.2 Will the behavioral interventions be brief in duration, harmless, painless, not physically invasive, and not likely to have a significant adverse lasting impact on the subjects?

Describe the specific behavioral intervention to be implemented, including timeframe and activities to be completed by subjects:

3.3 Does the investigator think the subjects will NOT feel embarrassed or be offended by the interventions?

Prowide rationale why subjects will not feel emborrassed or offended by the intervention:

3.4 Will data collection include visual or audio recording?

Describe how activities will be recorded, and specify which activities will be recorded:

3.5 Will the data be recorded in such a manner that the identity of the subjects cannot be readily ascertained directly or through identifiers linked to the subjects? Explain how subjects' identity will not be readily identifiable:

3.6 Would disclosure of subjects' responses outside of the research net reasonably place the subjects at risk of criminal or civil liability or be damaging to the subjects' financial standing, employability, educational advancement, or reputation?

Explain why disclosure of responses does not pose any of the risks identifled above:

3.7 Would disclosure of subjects' responses outside the research reasonably place the subjects at risk of criminal or civil liability or be damaging to the subjects' financial standing, employability, educational advancement, or reputation?

Describe the provisions to protect the privacy of subjects and to mointain the confidentiality of dato:

3.8 Are children (under age 18) excluded as subjects?

3.9 Are prisoners excluded as subjects (except for research aimed at involving a broader population that only incidentally includes Prisoners)?

$\sqrt{10}$


舟 Portland State

SU HUAN ESEAC

FOECT ON POFA

HPA\# 217195.18

Category 4: Secondary Research Without Consent

Does this study involve the use of Identifiable Private Information or Identifiable Biospecimens without obtaining consent from subjects?

$\square$ Yes $\otimes$ No

If no, skip to Category 5: Federal Demonstration Projects

If yes, complete questions below:

\begin{tabular}{|c|c|c|}
\hline $\begin{array}{l}4.1 \text { is the Identifiable Private Information or Identifiable Biospecimens publicly avallable? } \\
\text { List the source of the information, how the information will be accessed, and whot dato } \\
\text { will be recorded for research. Include in the response if a dato use agreement or special } \\
\text { permission is required to access the dato: }\end{array}$ & $\square$ & $\square$ \\
\hline $\begin{array}{l}\text { 4.2 Will the information be (1) recorded by the investigator in a manner that the identity of the } \\
\text { subjects cannot be readily ascertained directly or through identifiers linked to the subjects, } \\
\text { (2) the investigator will not contact the subjects, and (3) the investigator will not re-identify } \\
\text { subjects? } \\
\text { List the source of the information, how the information will be occessed and what will be } \\
\text { recorded by the investigator. include in the response if a data use agreement or special } \\
\text { permission is required to occess the dato: }\end{array}$ & $\square$ & $\square$ \\
\hline $\begin{array}{l}\text { 4.3 Does this research involve only information collection and analysis imvolving use of } \\
\text { identifiable health information when that use is regulated under the Health Insurance } \\
\text { Portability and Accountability Act (HIPAA) for the purposes of (1) health care operations, } \\
\text { (2) public health activities and purposes, or (3) research? } \\
\text { List the source of the information ond how it will be accessed: }\end{array}$ & $\square$ & $\square$ \\
\hline $\begin{array}{l}\text { What permission is required to access the dota: } \\
\square \text { HIPAA Authorization } \\
\square \text { Waiver of Authorization } \\
\square \text { Data Use Agreement } \\
\square \text { Other; describe: }\end{array}$ & & \\
\hline $\begin{array}{l}4.4 \text { Is this research conducted by, or on behalf of, a Federal agency using government- } \\
\text { generated or government-collected information obtained for non-research activities and } \\
\text { will this research generate identifiable private information that is or will be maintained on } \\
\text { information technology that is subject to and in compliance with the E-Government Act? }\end{array}$ & $\underset{\text { Yes }}{\square}$ & $\square$ \\
\hline $\begin{array}{l}\text { 4.5 Are Prisoners excluded as subjects (except for research aimed at involving a broader } \\
\text { population that only incidentally includes Prisoners)? }\end{array}$ & $\square$ & $\square$ \\
\hline
\end{tabular}

Proceed to next item - Cotegory 5: Federal Demonstrotion Projects. 
Category 5: Federal Demonstration Projects

Is this study a Federal research or demonstration project that is specifically conducted or supported by a Federal department or agency, or is otherwise subject to the approval of a Federal department or agency heads? $\square$ Yes $\otimes$ No

If no, skjp to Category 6: Taste and Food Quality Evaluation and Consumer Acceptance Studies

If yes, complete questions below:

5.1 Will the research or demonstration project be designed to study, evaluate, improve, or otherwise examine public benefit or service programs, including procedures for obtaining benefits or services under those programs, possible changes in or alternatives to those programs or procedures, or possible changes in methods or levels of payment for benefits or services under those programs?

List the federal agency conducting the demonstration project:

List name of public benefit or service program:

5.2 Will the research or demonstration project be published on a list of research and demonstration projects exempted under this category prior to commencing the research?

5.3 Are Prisoners excluded as subjects (except for research aimed at involving a broader population that only incidentally includes Prisoners)?

Proceed to next item - Category 6: Toste and Food Quality Evaluation and Consumer Acceptance Studies. 


\section{舟 Portland State}

BU HUAN RESEFO-

FOECT ON FOFF

HFPA 217195.18

Category 6: Taste and Food Quality Evaluation and Consumer Acceptance Studies Is this study a taste and food quality evaluation or consumer acceptance study? $\square$ Yes $\square$ No

If no, skip to Section 3: Protocol Submission

If yes, complete questions below:

6.1 Will the study involve taste and food quality evaluation and consumer acceptance studies where wholesome foods without additives are consumed, or food is consumed that contains a food ingredient at or below the level and for a use found to be safe, or agricultural chemical or environmental contaminant at or below the level found to be safe, by the Food and Drug Administration or approved by the Environmental Protection Agency or the Food Safety and Inspection Service of the U.S. Department of Agriculture? List the foods to be used in this study:

6.2 Are Prisoners excluded as subjects (except for research aimed at involving a broader population that only incidentally includes Prisoners)?

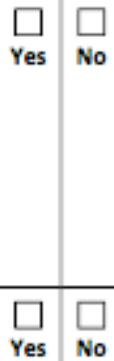

Proceed to Section 3: Protocol Submission to finalize and complete this application for submission. 


\section{Portats FOECT ON POEF UNIVERSITY \\ SECTION 3: Protocol Submission}

STeP If none of the exemption cotegories in this form apply to your proposed study, this form is NOT opplicable to your project. Please Complete Form 3: Initial IRB Review in order for the project to be reviewed by the IRB.

To request an exemption determination for the proposed research, email Research integrity at psuirb@odx.edu with the following completed materiais attoched (check all that appiy):

$\triangle$ form 1: Project Overwiew \& Pre-Screening (completed in Step 1)

$\triangle$ form 2: Exemption Certification (this form)

$\triangle$ form 4: Investigator Assurance

$\square$ Recruitment materiais (posters, fliers, scripts, emails, ads, etc.)

$\square$ Consent materials (consent statements, consent forms, etc.)

$\square$ instruments (surveys, interview questions, description of intervention, etc.)

$\square$ Permissions (documentation of permission to conduct research, school district approval, etc.)

$\square$ Doto Use Agreement(s)

$\square$ other; describe: 


\section{舟 Portland State}

PSU HUAN FESEACFOECT ON FOPF IFP\# 217195.19

\section{Human Research Protection Review FORM 4: INVESTIGATOR ASSURANCE}

Important: The Principal Investigator (and Student Investigator) must review each of the investigator responsibilities outlined below and check each box when understood. Each box must be checked in order for the submission to be processed by ORI.

\section{SECTION 1: INVESTIGATOR RESPONSIBILITIES}

1. I understand PSU's policies concerning research involving human subjects and that I have ultimate responsibility for the protections of the rights and welfare of human participants, the conduct of this study, and the ethical performance of this research.

2. I will maintain IRB related documents (including signed consent forms, as applicable) for a minimum of three years after the completion of the study, or for a minimum of five years after completion if the study is funded (this may vary depending on the funding agency requirements).

3. I understand it is my responsibility to ensure that all study personnel receive the mandatory human subjects' research protection education (cलll Training) and to maintain a training documentation file.

4. I agree to:

- Comply with all PSU HRPP policies, decisions, conditions and requirements.

- Obtain prior approval from the IRB before amending or altering the research protocol or changing the approved consent/assent form.

- Notify the Office of Research Integrity of any related financial conflict not already disclosed.

- Notify the Office of Research Integrity (and when applicable, the granting agency) of all adverse events, unanticipated problems, or protocol deviations in a timely manner.

5. I certify that:

- This research will be conducted in accordance with the principles of The Belmont Report.

- The time and resources are available to complete this project.

- The equipment, facilities, and procedures to be used in this research meet recognized standards for safety.

- New information that may affect the risk-benefit assessment for this research will be reported to the Office of Research Integrity.

- Adequate supervision of all research study personnel will be ensured.

- The information provided in this application and all attachments is complete and correct.

\section{SECTION 2: INVESTIGATOR SIGNATURES}

By signing below, the Principal Investigator (and Student Investigator, if applicable) agrees to the list of requirements detailed in the assurance above. PLEASE TYPE NAME BELOW.

Principal Investigator/Faculty Advisor: Christopher Student Investigator: Adriana Cordova-Perez

Carey

Date: 01/21/2021

Date: 02/04/21 


\section{胥 Portland State \\ BU HUAN FESAC- \\ FOECI ON FOFF \\ सPF\# 217195.18}


Questions:

What was your childhood like?

Were both of your parents in your life?

Did you have the support of an extended family?

Do you have siblings? If so how many?

Are you the youngest child or oldest sibling?

Were you ever part of delinquent behaviour?

Involvement in sports/clubs.

Did you finish high school?

How was your attendance at school?

How was your educational experience?

Did you take any classes while incarcerated?

What classes were offered to you in high school?

Were you ever encouraged to take honors classes?

How did you become part of the juvenile justice system?

Once part of the system what did you learn about it?

Did you participate in any programs when you were incarcerated?

Were you ever involved in any program aimed to help stop you from becoming part of the juvenile justice system?

How long was your sentence? Did you serve the whole time?

Did you have visits?

What did a typical day in the correction facility look like?

Did you have a point while serving your sentence where you decided to turn your life around?

Who/what motivated you to do better?

What are the most commonly used residential placement options for committed youth?

How do states define the purpose of their juvenile justice system?

How does each youth correctional facility differ from one another?

What is the process of deciding where the youth will be sent to like? 


\section{Portland State}

\section{Consent to Participate in Research (No Signature)}

Project Title: Exploring the Interactions and Interventions of the Juvenile Justice System through a Case Study Approach

Population: Juvenile Offender, Interview

Researcher: Adriana Cordova-Perez, Criminology

Portland State University

Researcher Contact: acor2@pdx.edu / 503-409-5439

You are being asked to take part in a research study. The box below shows the main facts you need to know about this research for you to think about when making a decision about if you want to join in. Carefully look over the information in this form and ask questions about anything you do not understand before you make your decision.

Key Information for You to Consider

- Voluntary Consent. You are being asked to volunteer for a research study. It is up to you whether you choose to involve yourself or not. There is no penalty if you choose not to join in or decide to stop.

- Purpose. The reasons for doing this research are have a better understanding of point of intervention in the juvenile justice system.

- Duration. It is expected that your part will last approximately two hours of interview.

- Procedures and Activities. You will be asked to answer questions provided during the interview related to the research topic.

- Risks. Some of the possible risks or discomforts of taking part in this study include having to re-live traumatizing life moments while answering questions related to their life.

- Benefits. Some of the benefits that you may expect include no direct benefit, but the researcher hopes to learn more about points of intervention in the juvenile justice system.

- Options. Instead of taking part in this study, you could participation is voluntary, and the only alternative is to not participate.

What happens to the information collected?

Information collected from you for this research will analyze what can be learned about the criminal justice system from exploring the life of a juvenile offender. The findings will be used for a senior honors thesis project.

How will I and my information be protected?

We will take measures to protect your privacy including all identities such as name, date of birth, home town and other locations will be script from the final report. Despite taking steps to protect your privacy, we can never fully guarantee that your privacy will be protected.

To protect all of your personal information, we will use an identity data only password on a drive/computer. If emails are sent email will be encrypted. Identities will be script from final report. Despite these precautions, we can never fully guarantee that all your study information will not be revealed.

What if I want to stop being in this research? 
BSU HUAN FESECO

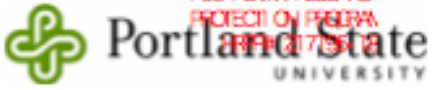

You do not have to take part in this study, but if you do, you may stop at any time. You have the right to choose not to join in any study activity or completely stop your participation at any point without penalty or loss of benefits you would otherwise get. Your decision whether or not to take part in research will not affect your relationship with the researchers or Portland State University.

Will it cost me money to take part in this research?

There is no cost to taking part in this research, beyond your time.

Will I be paid for taking part in this research?

Participant will not be compensated for the participant in this study.

Who can answer my questions about this research?

If you have questions or concerns, contact the research team at:

Adriana Cordova-Perez

Acor2@pdx.edu

Who can I speak to about my rights as a research participant?

The Portland State University Institutional Review Board ("IRB") is overseeing this research. The IRB is a group of people who review research studies to make sure the rights and welfare of the people who take part in research are protected. The Office of Research Integrity is the office at Portland State University that supports the IRB. If you have questions about your rights, or wish to speak with someone other than the research team, you may contact:

Office of Research Integrity

PO Box 751

Portland, OR $97207-0751$

Phone: (503) 725-5484

Toll Free: $1(877) 480-4400$

Email: psuirb@pdx.edu

Consent Statement

I have had the chance to read and think about the information in this form. I have asked any questions I have, and I can make a decision about my participation. I understand that I can ask additional questions anytime while I take part in the research.

I agree to take part in this study

I do not agree to take part in this study 


\section{Bibliography:}

Ben-Joseph, E. P. (Ed.). (2018, June). Bonding With Your Baby (for Parents) - Nemours KidsHealth. KidsHealth. https://kidshealth.org/en/parents/bonding.html.

Bergdahl, Jacqueline, Twill, Sarah, Norris, Michael, \& Ream, Matthew. (2015). Assessing the Prevention of Juvenile Delinquency: An Evaluation of a Court-Based Delinquency Prevention Program. Family Court Review, 53(4), 617-631. https://doi.org/10.1111/fcre.12177

Chamiel Elad;Walsh, Sophie D, Chamiel, Elad, \& Walsh, Sophie D. (2018). "House Arrest" or "Developmental Arrest"? A Study of Youth Under House Arrest. International Journal of Offender Therapy and Comparative Criminology : Official Organ of the Association for Psychiatric Treatment of Offenders (APTO)., 62(14), 4381-4402. https://doi.org/10.1177/0306624X18779183

Greenwood, P. (2008). Prevention and Intervention Programs for Juvenile Offenders. The Future of Children, 18(2), 185-210. https://doi.org/10.1353/foc.0.0018

Henry, Kimberly L, Knight, Kelly E, \& Thornberry, Terence P. (2011). School Disengagement as a Predictor of Dropout, Delinquency, and Problem Substance Use During Adolescence and Early Adulthood. Journal of Youth and Adolescence, 41(2), 156-166.

Mann, Emily A, \& Reynolds, Arthur J. (2006). Early Intervention and Juvenile Delinquency Prevention: Evidence from the Chicago Longitudinal Study. Social Work Research, 30(3), 153-167.

https://doi.org/10.1093/swr/30.3.153

Opsal, Tara, Aguilar, Jade, \& Briggs, Steven. (2019). The Promises and Pitfalls of Engaging Male Juvenile Offenders in Gender Violence Prevention and Bystander Education. Journal of Interpersonal Violence, 34(21-22), 4384-4403. https://doi.org/10.1177/0886260516675466 